\title{
VAMPIRIC SEDUCTION AND VICISSITUDES OF MASCULINE IDENTITY IN BRAM STOKER'S DRACULA
}

\author{
By Dejan Kuzmanovic
}

MOST CRITICS WHO DISCUSS VAMPIRISM in Bram Stoker's Dracula (1897) as a type of seduction focus on the symbolic corruption of English womanhood as the central theme in the novel and emphasize the significance of "the seduction of Lucy and Mina, to which the experience of Harker at Castle Dracula," according to Phyllis Roth, "provides a preface." Roth believes that Harker's role as "a hero, one whose narrative encloses the others and with whom, therefore, one might readily identify ... is a defense against the central identification of the novel with Dracula and his attacks on the women" (61-62). ${ }^{1}$ Other critics have observed that, in addition to preserving the symbolic purity of Englishwomen, Stoker's novel is also about the symbolic education of Englishmen, through which members of different professions and classes that carry the bourgeois order learn to work together and, pooling their various backgrounds and knowledge and combining tradition with progress in order to save the women, confirm the strength of their own manhood, and destroy the symbolic threat of the vampire. ${ }^{2}$ Both groups of critics, however, tend to overlook the unique position that the young solicitor Jonathan Harker occupies in the narrative: he is the only character who is both an object of the vampire's seduction and an agent of his destruction. ${ }^{3}$ While some critics pay due attention to Harker's sensational seduction by Dracula and the three vampiric women in the first part of the novel, they either simplify the meaning of that seduction or underestimate Harker's continuing significance in the rest of the novel because he gradually blends into the group of several valiant vampire hunters. At the same time, his membership in that group has been too easily taken for granted by most critics. What has remained insufficiently explored is the significance of the twofold nature of Harker's experiences: he yields to Dracula's seduction and then recuperates from its consequences by participating in vampire hunting. It is through Harker's experiences throughout the narrative that the paradox of the novel's simultaneously conservative and subversive tendencies becomes most conspicuous.

My analysis of Harker's role in the novel builds on recent critics' resistance to earlier excessive critical emphasis on sexual transgression as the key theme of the novel, and I contribute to their efforts to stress work and the rise of professions as equally important in the narrative. For example, Jennifer L. Fleissner suggests that the novel is "as much 
about [Mina's] secretarial work as it is about sex" (417) and argues that it is restrictive to assume "that the novel is 'really' pointing to a repressed sexuality at every turn, rather than mobilizing discourses of the sexual in order to explain potentially even more outré technological phenomena" (417). She adds that we should be attentive to "the way in which the discourses of the sexual may proliferate precisely in order to mask the part played by other discourses . . in organizing gender" (442). While Fleissner focuses on Mina's role as the gatherer, organizer, and interpreter of the information about Dracula and argues that the novel represents clerical work as proper rather than irredeemably corrupting for a bourgeois woman, I am interested in how the proliferation of sexual anxieties and repressed desires in the novel, rather than being the ultimate point of the narrative in themselves, interact with Harker's gender and professional anxieties in order to stage a contained and temporary identity crisis, which finally results in a restructuring of his ego. One effect of this approach is to counteract Christopher Craft's influential interpretation of Harker's experience, which, in my view, overemphasizes the transgressive role of repressed homosexuality in Dracula. While rightly pointing out Harker's relevance throughout the novel and convincingly showing how homosexual desire in it is heterosexually mediated and displaced into homosociality, Craft less persuasively insists that "the narrative's originary anxiety... derives from Dracula's hovering interest in Jonathan Harker" (74; my emphasis) implying that homoerotic desire is a primary force in the novel, suppressed and displaced because of the homophobic proscriptions of Stoker's culture. I argue, however, that homoerotic desire, while initially a manifestation of Harker's faltering masculine identification, eventually functions as a defensive mechanism of Harker's ego helping to prevent a more radical identity crisis. On the other hand, I also argue against reducing Harker's anxiety primarily to a sense of professional inadequacy. According to Jasmine Yong Hall, Harker's profession "is central to an understanding of the novel's representation of the threat of sexuality and the blurring of gender roles" (99). She argues that the novel indicates an anxiety about the servile, emasculating position in which the professional male must place himself, symbolized by "the female role of subservience which Harker must adopt as a solicitor in relation to his client, Dracula" (99). While she usefully emphasizes Harker's anxiety about professional emasculation, Hall does not recognize that an anxiety about adopting a mature and independent professional identity informs Harker's actions and descriptions with equal power, nor does she acknowledge the psychological complexity of overcoming these anxieties and establishing socially prescribed professional and gender identities. In my reading, Harker's reluctant sexual and professional development - hindered by his servile relation to Dracula, occasional feminine identification, and glimpses of homoerotic desire - is symptomatic of a deeper psychic process in which Harker's ego, in response to external pressures of his impending initiation into business and marriage, allows its own limited, temporary destabilization in order to be re-stabilized in a modified form which can accommodate these external pressures. It is this process that I describe as the process of seduction.

\section{Laplanche's Theory of Seduction and Psychoanalytic Readings of Dracula}

THE FRENCH PSYCHOANALYST JEAN LAPLANCHE'S so-called "general theory of seduction" maintains that seduction is a moment of an encounter with the unconscious of the other. As such, while remaining sexual in its nature, seduction is taken out of the realm of what 
Laplanche dismissively calls "anecdotal scenes à la Nabokov" (New Foundations 120) and is seen as having a crucial role in establishing and maintaining personal identity. ${ }^{4}$ According to Laplanche, the original seduction is the moment of a child's exposure to the enigmatic, sexual message of an adult - enigmatic because it originates in the adult's unconscious which founds the child's own unconscious. This is the moment of the formation of the subject's ego, and from then on, the subject maintains two contradictory tendencies: to close in on itself into an illusion of a stable, authentic identity, but also to open itself up to the "enigmatic messages" of the others (Laplanche, "Theory" 657-62). While Laplanche focuses on the original or "primal" seduction, seduction is also a repeated occurrence through which both the coherence of the ego and the de-centering effects of the unconscious are maintained throughout life. Seduction, therefore, both stages a contained, controlled crisis of the subject's identity and enables the resolution of that crisis and the re-consolidation of that identity. In this way, the subject's ego is constantly re-established in the ways necessitated by the subject's circumstances, while the nature of the specific crisis depends on the culturally available anxieties of the moment. Gynophobia, homophobia, and xenophobia are some of the anxieties that clearly play a part in Stoker's novel and give a variety of faces to Jonathan Harker's psychic crisis at the novel's center, but none of them has a privileged position as the source of the crisis. Harker's identity crisis is ultimately precipitated by nothing else than his ego's inevitable internal resistance to its own coherence and stability in circumstances that pressure him to endorse and fully internalize certain aspects of mature masculinity heterosexual romance, professional advancement, climbing up the social ladder, entering a tight social circle of professional men who lead the society. In order for this internalization to take place without overwhelming and exploding the fragile boundaries of Harker's ego, his identity needs to undergo a contained crisis through which it will restructure itself and strengthen the illusion of its coherence and stability. In Stoker's novel that process takes the form of Dracula's seduction of Harker, or, to be more precise, the form of Harker's exposure to the seductively alien nature of the vampire.

Ever since Maurice Richardson's 1959 essay "The Psychoanalysis of Ghost Stories," in which he reads Dracula as an expression of Stoker's repressed fantasies and calls it, memorably, "a kind of incestuous necrophilous, oral-anal-sadistic all-in wrestling match" (427), psychoanalytic readings of this novel have abounded. ${ }^{5}$ Many of them, however, posit a simplistic equation between the vampire and the unconscious or repressed desires sometimes in glib phrases such as "Transylvania is Europe's unconscious" (Geoffrey Wall, qtd. in Johnson 237) or "Dracula acts out the repressed fantasies of the others" (Roth 61). While not necessarily incorrect, such readings tell merely a part of the story. If in some relatively obvious ways Dracula stands for transgression, he also stands for - or, paradoxically, enables - a recuperation of stability and order. In psychoanalytic terms, Dracula is as much a ruse of the ego conjured up for the purpose of protecting the ego against disruptions as he is the initiator or facilitator of such disruptions. Rather than a projection or embodiment of any particular repressed psychic content, the vampire, as Foster suggests, is "the projection of the childlike immortality onto an adult body" (492), the sense of immortality the child has before his ego is formed and he enters the symbolic realm. If the vampire stands for anything, that would be the lack of a sense of disconnection between one's self and the world, that lost state of complete fulfillment, which precedes the formation of the ego, while the desire to return to that state perpetually jeopardizes the adult subject's precarious self-identification. The vampire's seduction is partly a trace of, or a promise of 
a return to, that pre-symbolic, pre-ego-formation state of complete fulfillment ${ }^{6}$ inasmuch as he is an immortal, inexplicable, shape-shifting force whose presence is mysteriously felt by humans; on the other hand, as soon as Dracula acquires a particular shape, is assigned a particular motivation as well as a set of positive characteristics (things he can or cannot do, for example) - in other words, as soon as Dracula is diagnosed, primarily by Van Helsing he becomes a figuration conjured up by the ego for the purposes of preventing its further destabilization. ${ }^{7}$ While the vampire's shape-shifting presence-baffling, elusive, indefinablethreatens to pry open the victim's ego and enforce its exposure to unconscious desires and anxieties (thus exposing the indeterminacy of ego-forming structures, such as gender and sexual orientation), the imaginary, unified image of the vampire as a knowable, diagnosable, and therefore destroyable monster is a defensive mechanism by means of which the victim's ego protects itself against the disruptive forces of its own unconscious. ${ }^{8}$ Through the fantasy of a coherent monstrous self (the other without) and through the drama of being temporarily vulnerable to its monstrous seductiveness, the victim's ego distracts itself, as it were, from the encounter with the unconscious (the other within), and thus the victim is ultimately able to detach his sense of self from the monstrous desire to yield to the vampire's seduction. In this sense, the seduction makes the victim's ego possible by jeopardizing it.

\section{Mina's Fiancé / Solicitor's Clerk: Harker's Pre-Nuptial Apprenticeship}

THE MOST CONSISTENT NARRATIVE LINE in Dracula is the one following the initial instability of Harker's masculine identity and then his gradual initiation into the kind of masculinity on which England can rely for its future. While the other four vampire hunters - Van Helsing ${ }^{9}$ and Lucy's three suitors: Dr. Steward, Lord Arthur, and Quincey Morris - have already proved their virility through shared adventures in the past, Harker's initial link to them is only through his wife Mina, Lucy's best friend, and he is significantly excluded from the early scenes of symbolic male bonding over Lucy's dying and dead body. ${ }^{10}$ This exclusion emphasizes his initial difference from the kind of ideal masculinity the other four men already embody but which Harker gradually acquires through his participation in vampire hunting. Therefore, Harker's encounters with Dracula in this narrative of masculine initiation first occasion a contained, limited crisis of Harker's identity, fleshing out his original unwitting resistance to sexual and professional maturation, but then they actually allow him to contain that inevitable crisis and establish for himself a more sexually and professionally stable masculine identity necessary for being one of the symbolic saviors of England.

At the outset of Stoker's novel, Jonathan Harker is exposed to the pressure of a double initiation into the states of professional and sexual maturity: he has just become a full-blown solicitor and he is engaged to be married. The diary he writes during his visit to Transylvania, where he goes to assist Count Dracula in the business of buying a house in London, reveals his anxiety about, and even subconscious resistance to, endorsing this proper middle-class professional and heterosexual - masculine identification. From the very beginning, Harker's diary projects the turbulence and uncertainty within his own mind onto the land which he encounters and obsessively describes as a geographically, ethnically, and temporally liminal and unruly space that overruns boundaries of various kinds: Dracula's home is "on the borders of three states," "the center of some sort of imaginative whirlpool," in a place that is a "whirlpool of European races" and languages, "one of the wildest and least known portions 
of Europe," of which there are no precise maps and where trains are always late (Stoker 8-9, 42; chs. 1-2). But the strangeness of Transylvania merely provides the vocabulary and an alibi for the expression of the instability of Harker's self-identification as a rational, selfdisciplined English gentleman. At times Harker appears to be on the verge of an awareness of the strangeness within his own mind: "I think strange things, which I dare not confess to my own soul" (29; ch. 2).

However, Harker's unwitting resistance to endorsing a mature masculine identity is even more tellingly betrayed by his repeatedly forgetting about his promotion and still thinking of himself as a solicitor's clerk. He corrects himself only after realizing that "Mina would not like that" $(25 ;$ ch. 2$)$, the first in a series of indications in the narrative that Harker's fiancée, and then wife and business partner, is more ambitious, resourceful, and active than Harker himself. That Harker's professional situation and gender identification are mutually defining and equally unstable becomes quite clear in the letter of introduction to Dracula in which Mr. Hawkins, Harker's employer, explicitly implicates Harker's manhood in his professional growth: "He is discreet and silent, and has grown into manhood in my service. He shall be ready to attend on you when you will during his stay, and shall take your instructions in all matters" (27; ch. 2; emphasis added). While advertising the supposed maturity of Harker's manhood, this letter implicitly undermines it by placing Harker in a subservient position beyond what is necessitated by his professional task and by implicating his manhood in a homosocial exchange between Hawkins and Dracula, in which Harker's position is not unlike Lucy's position in strengthening the bond between her three suitors. As long as Harker is in Transylvania, his professional stagnation is perpetuated and becomes part and parcel with his faltering masculine identification. This is why, as we shall see, Harker's recuperation from the destabilizing experience in Transylvania must simultaneously include both a speedy wedding and a fast-track promotion.

But before that sexual and professional maturation can take place, Harker must experience a more profound crisis, which will subdue his unconscious resistance to such maturation and initiate his adoption of a more stable masculine self-identification. The lack of such identification early in the narrative is indicated not only by his servile professional position in Castle Dracula, but also in his consistent articulation of his situation as analogous to that of an imprisoned and endangered heroine. One can easily imagine the following exclamations uttered by Clarissa, Pamela, or Emily in the depths of Udolpho: "The castle is a veritable prison, and I am a prisoner" (39; ch. 2); "Then the horror overcame me, and I sank down unconscious" (56; ch. 3); "I came back to my room and threw myself on my knees. It is then so near the end? To-morrow! To-morrow! Lord, help me, and those to whom I am dear!" (70; ch. 4). In fact, these are all sentences from Harker's journal. The first part of the novel performs a gender inversion of the generic motif shared by both gothic romances and Samuel Richardson's epistolary novels: the heroine is kept captive by an aggressive masculine figure who proclaims to wish her well but whom she sees as a threat to her integrity. Harker even compares himself to Shahrazad by commenting that "this diary seems horribly like the beginning of the "Arabian Nights"' (43-44; ch. 3).

However, although it is his passive yielding to captivity that initially marks him as feminine, Harker's own actions further compromise his masculine identification. In spite of Dracula's warning not to sleep in any other part of the castle but his own rooms because "there are bad dreams for those who sleep unwisely" (47; ch. 3), Harker ventures beyond his quarters and discovers a room which, by decorations and furniture, he judges to have been 
"occupied by the ladies in bygone days" (51; ch. 3). In this room, his feminine identification strengthens even more: "Here I am sitting at a little oak table where in old times possibly some fair lady sat to pen, with much thought and many blushes, her ill-spelt love-letter, and writing in my diary in shorthand all that has happened since I closed it last" $(51 ;$ ch. 3$)$. This emphatic juxtaposition of the image of the lady with the image of Harker, both writing about their feelings and awaiting their destiny, is immediately reinforced by Harker's move from the lady's seat into her bed: "I determined not to return tonight to the gloom-haunted rooms, but to sleep here, where, of old, ladies had set and sung and lived sweet lives whilst their gentle breasts were sad for their menfolk away in the midst of remorseless wars" (52; ch. 3 ). This sentence, which starts with Harker as a protagonist and ends by substituting the ladies for him, confirms Harker's strong identification with these ladies. It also implies that Harker begins to cultivate feelings for Dracula other than those of repulsion and fear. Dracula has emphasized to Harker that he comes from a tradition of warriors and that he sees himself as an heir to that tradition, which makes it possible to see Harker's thoughts about the ladies being sad for the warriors as an expression of his own sympathy, and perhaps desire, for Dracula. After all, fearing that he may be going mad, Harker admits to himself: "If I be sane, then surely it is maddening to think that of all the foul things that lurk in this hateful place the count [Dracula] is the least dreadful to me" (51; ch. 3). At the same time, however, Harker's fantasizing about the ladies expresses his suppressed heterosexual desire, which then finds its manifestation in the dream/event with the three vampiric women that he experiences while in the ancient ladies' room.

Even though later rationalizations in the novel encourage us to understand this experience as real, Harker's journal itself leaves it entirely uncertain how much of it may be Harker's fantasy, a manifestation of his psychic turbulence. When Harker encounters the vampiric women again a little bit later in the narrative, their appearance is described more decidedly as a figment of his unconscious: "I felt myself struggling to awake to some call of my instincts; nay, my very soul was struggling, and my half-remembered sensibilities were striving to answer the call" ( 63 ; ch. 4). His reawakened "half-remembered sensibilities" are clearly sexual in nature, but this complicated scene of seduction, in which Harker describes himself as being desired both by three vampiric women and by Dracula himself, defies any easy, ego-driven categories, such as heterosexual or homosexual.

Lying in the ancient ladies' bed, whether awake or asleep, Harker is first visited by three voluptuous vampire-ladies, who instigate in him "a wicked, burning desire that they would kiss [him] with those red lips" (53; ch. 3). Away from his fiancée and from the moral and social norms of England, Harker's ego loosens control over his desire, which initially seems hyper-heterosexual: he wants to be illicitly kissed by no less than three women. ${ }^{11}$ But the heterosexual character of Harker's desire for the vampiric women is immediately troubled by the fact that his dream can be interpreted as a fantasy of fellatio that threatens to turn into castration:

The fair girl went on her knees, and bent over me, simply gloating. There was a deliberate voluptuousness which was both thrilling and repulsive, and as she arched her neck she actually licked her lips like an animal... . Lower and lower went her head as the lips went below the range of my mouth and chin and seemed about to fasten on my throat... . I could feel the soft, shivering touch of the lips on the super-sensitive skin of my throat, and the hard dents of two sharp teeth, just touching and pausing there. I closed my eyes in a languorous ecstasy and waited - waited with beating heart. (54; ch. 3) 
The emphasis on the woman's mouth, lips, and teeth, as well as her going on her knees and moving her head lower and lower, connote fellatio, even though Harker's weakened ego is still strong enough to substitute the throat, with its "super-sensitive skin," for the penis, but the woman's sharp teeth and her impending bite clearly endanger the throat/penis and suggest castration, which Harker, less and less invested in maintaining his own masculinity, almost welcomes, in an ultimately masochistic impulse.

If the first part of the scene seems to stress the heterosexual character of Harker's unruly desire, although complicated by the emasculating desire for castration, it is Dracula's sudden bursting in upon this bizarre foursome that makes the circulation of desire in the scene even more ambiguous. Dracula hurls the woman away from Harker, thus saving him from castration, and pronounces the words that provoked much critical discussion: "How dare you touch him, any of you? How dare you cast eyes on him when I had forbidden it? Back, I tell you all! This man belongs to me!" (55; ch. 3$)$. And when the women then accuse him of not being able to love, "the Count turned, after looking at [Harker's] face attentively, and said in a soft whisper: 'Yes, I too can love; ... I promise you that when I am done with him you shall kiss him at your will'" (55; ch. 3). As the women disappear and Dracula remains next to the bed with the aroused Harker in it, Harker puts in use a self-defensive and self-denying mechanism worthy of Clarissa and faints. The next thing he is aware of is awaking in his own bed and realizing that Dracula must have carried him there and undressed him. This makes him rather glad because "nothing can be more dreadful than those awful women, who were - who are - waiting to suck my blood" ( 57 ; ch. 4 ; emphasis added). Harker's apparent obliviousness to the fact that Dracula as well might wish to suck his blood - or do whatever else the women were about to do - goes hand in hand with his denial of his own preference to be Dracula's victim rather than the women's.

However, the ambiguous eroticism of Harker's exchanges with both Dracula and the vampiric women does not imply, as Craft insists, that "an implicitly homosexual desire achieves representation as a monstrous heterosexuality, as a demonic inversion of normal gender relations" (75). Craft's assumption that Harker's fantasy is a displaced momentary acknowledgment of the hidden truth of his suppressed homosexual desire simplifies the role of homoeroticism in the novel. Homoeroticism functions here as a defense mechanism which allows Harker's ego to fend off a more radical identity crisis by giving shape to an emotion which his rational self can then condemn and deny. After all, what is the usefulness of concluding that in his unconscious, exposed in this hallucinatory scene, Harker makes a homosexual object choice when, as Freud famously puts it, "all human beings are capable of making a homosexual object-choice and have in fact made one in their unconscious" (11n; emphasis added). What is more interesting is the effect that this moment of homoerotic recognition has of abruptly interrupting the increasing destabilization of Harker's identity as a professional middle-class gentleman and of pushing him into a transformative illness which will initiate the process of reclaiming and strengthening that masculine identity. In order for such healing to occur, Harker's ego needs to experience itself as threatened, not by its own intrinsic instability, but by a kind of monstrosity which is defined enough in cultural imagination in order to be rationally denied and removed in its entirety. One such "monstrosity" in Victorian cultural imagination is homoerotic desire. In this way, homoerotic desire actually serves to restore and strengthen Harker's masculine rationalism and self-discipline, which have been dissipating during his previous experiences in Transylvania. ${ }^{12}$ 
But this restoration cannot be sudden because the cost of the restructuring of Harker's ego through a temporary, contained identity crisis is the danger of a looming awareness that the categories of the ego (gender, sexual, and professional identities) are precarious and conventional rather than stable and authentic. It is this brief tantalizing possibility that the ego's intrinsic weakness could be consciously realized that is suggested by Harker's temporary identification with the vampire: Harker runs away by imitating Dracula's crawling down the walls of the castle ("Why should not I imitate him?" - Stoker 65; ch. 4); Dracula goes about wearing Harker's clothes making some of his victims believe that Harker is the monster (62; ch. 4). ${ }^{13}$ After all, although Harker never makes it clear in his diary whether Dracula has feasted on him or not, there are several reasons to believe that Dracula has sucked Harker's blood. We never learn what happens after Dracula saves the fainted Harker from the vampiric women and takes him to his room, but when Harker wakes up and before he flees the castle, he ventures to Dracula's room only to find him in his coffin bloated with blood and rejuvenated, "like a filthy leach, exhausted with his repletion" (71; ch. 4). Obviously, Dracula has feasted on somebody, and since there are no other humans in the castle and Dracula's leaving the castle that night is not mentioned, it is fair to conclude that Harker has become Dracula's victim, potentially turning from someone whose masculine self-identification is buttressed by the projection of the undesirable internal ambiguities onto the monstrous other into someone who knows these ambiguities to be intrinsically his own. Harker reveals this threat when he explains that he will write a letter to his fiancée Mina, but "without the horrors which I may only surmise. It would shock and frighten her to death were I to expose my heart to her" (59; ch. 4; emphasis added). It is not the obscure monstrosity of the vampire or his bizarre country but of Harker's own heart that would shock Mina, as indeed many a Victorian woman would be shocked to learn that her fiancé's identity may not be unambiguously heterosexual, masculine, and monogamous.

The potential of consciously realizing the secrets of his own heart, the intrinsic instability of his own ego, must dissipate in the rest of the narrative if Harker is to consolidate his masculine identity and earn the membership in the band of men capable of saving England from the threat of the vampire. The lengthy, gradual, and somewhat hesitant character of that process suggests the remaining ambivalence with which Harker endorses his reconstituted masculine identification. The nun who informs Mina about Harker's recovery in a Hungarian hospital after his escape from Dracula's castle has a sense of how difficult Harker's recovery must be and advises Mina to be "careful with him always that there may be nothing to excite him of this kind for a long time to come; the traces of such illness as his do not lightly die away" (132; ch. 8). Harker's "violent brain fever" (131; ch. 8) translates the identity crisis he has experienced in Transylvania into somatic symptoms, turning it into something that can be healed. Complete healing, however, depends on Harker's ability to put behind him the uncertainties - related both to his professional situation and to his sexuality prior to marriage that have plagued his masculine identification. Consequently, the first steps in his recovery must be to replace his old Master, Mr. Hawkins, and to marry Mina.

\section{His Own Master: Marriage and/as Business}

THE HARKERS' HASTY AND IMPROVISED wedding, which occurs in a hospital with Harker barely recovered from his brain fever, appears to be very much an effort to neutralize or suppress Harker's experiences in Transylvania. He makes Mina's agreement with this 
suppression practically a part of their wedding vows. Here is, as recounted by Mina, Harker's solemn address to her just before their wedding, regarding his Transylvanian journal:

\footnotetext{
"Wilhelmina" - I knew then that he was in deadly earnest, for he has never called me by that name since he asked me to marry him - "you know, dear, my ideas of the trust between husband and wife: there should be no secret, no concealment. I have had a great shock, and when I try to think of what it is I feel my head spin round, and I do not know if it was real or the dreaming of a madman. You know I have had brain fever, and this is to be mad. The secret is here, and I do not want to know it. I want to take up my life here, with our marriage.... Are you willing, Wilhelmina, to share my ignorance? Here is the book. Take it and keep it, read it if you will, but never let me know; unless, indeed, some solemn duty should come upon me to go back to the bitter hours, asleep or awake, sane or mad, recorded here." (138-39; ch. 9)
}

Even though Harker leaves Mina the option to read his journal at her will, he makes it clear that he wishes she would share his ignorance. Indeed, in spite of the stated ideal of absolute openness in marriage, for this marriage to work, the husband's sexualized adventures with multiple women and a mysterious man, whether real or fantasized, would seem better kept secret. Inasmuch as the marriage guarantees Harker's stabilized masculine identity, his gender and sexual ambiguity must be external to it.

Not only does Mina accept Harker's terms, but she makes this secret about his premarital experiences, or about his unconscious fantasies, her "wedding present" (139; ch. 9), the very symbol of their union. As Harker is resting after the wedding ceremony, Mina does the following:

I took the book from under his pillow, and wrapped it up in white paper, and tied it with a little bit of pale ribbon which was round my neck, and sealed it over the knot with sealing-wax, and for my seal I used my wedding ring. Then I kissed it and showed it to my husband, and told him that I would keep it so, and then it would be an outward and visible sign for us all our lives that we trusted each other; that I would never open it unless it were for his own dear sake or for the sake of some stern duty. (139; ch. 9)

While the wedding ring literally seals the secret of Harker's faltering masculinity preceding the marriage, the whiteness of the wrapping paper and the paleness of the ribbon should symbolize the innocence of Mina's wifely gesture of trust and submission to her husband's wish. Characteristically for Mina, though, she indicates that she may suspect more than she avows when she writes to Lucy that Harker "does not remember anything that has happened to him for a long time past. At least, he wants me to believe so, and I shall never ask" (137; ch. 9; emphasis added).

It is important that both Harker and Mina anticipate that their pact of secrecy might be breached for the sake of "some solemn duty," "some stern duty" (139; ch. 9). The implication is that their marriage is a necessary but insufficient condition of Harker's recuperation as a rational, self-disciplined, self-controlled, middle-class Englishman. In addition, Harker's submissive professional situation as a man in another man's service must change and he must show himself to be worthy of joining the band of vampire hunters whose stable masculinity, shored up by their appropriate attitudes toward professions, class, money, and women, guarantees the stability of the nation itself. Therein lies the enormous symbolic significance 
of Harker's inheriting the business of the suddenly diseased Mr. Hawkins, Harker's former employer, and of the fact that it is Harker himself who eventually destroys Dracula.

I wish to emphasize, however, that throughout this process of achieving professional stability and social significance, Harker's sexual relationship with Mina - his continuing negotiation of a mature heterosexual masculinity within marriage - continues to play a significant, if ambiguous, part. It is true that Mina apparently accepts the role of a dutiful, trustful wife who proudly calls her husband "a solicitor, a partner, rich, master of his business" (221; ch. 13) and who would never dream of questioning his masculinity. It is also true, as Hall points out, that Mina becomes her husband's employee by typing out his journal, thus taking upon herself "all the feminine attributes which had threatened to emasculate her husband" (109) and transforming his personal experiences, with all their ambiguities and contradictory impulses, "into a public text, a text which presents the professional man as the unified liberal subject, both knowledgeable and powerful" (110). Harker himself, initially reluctant to remember his Transylvanian adventures, remarks that reading Mina's text has "made a new man of me.... I felt impotent, and in the dark, and distrustful. But, now that I know, I am not afraid, even of the Count" (Stoker 242; ch. 14). However, it has remained unobserved by Hall and other critics that, until the very end of the narrative, the recuperation of Harker's masculinity depends on the gradually diminishing ambiguity of his relationship with Mina, including their sexual relationship, and that Dracula once again serves the paradoxical purpose of destabilizing their relationship only to facilitate its final consolidation.

The Harkers' marriage is described in the novel more as a condition of rapid professional success than a fulfilled sexual union. Not only does Mina see her work "as an extension of her marital duties" (Fleissner 428) but "the sexual elements that presumably exist in their relationship are never revealed, much less discussed" (Bentley 26). In fact, sexual consummation of this marriage seems to be deliberately postponed - first by Harker's illness and then by Dracula's defilement of Mina - until the very end of the narrative, when both Harker and Mina are reclaimed as the proper middle-class couple whose son is meant to symbolize the future free of the threat of the vampire. The actual consummation, then, cannot occur as long as Mina - by rushing to Hungary to marry Harker, by typing out his diary, by using her, as Van Helsing puts it, "man's brain" (Stoker 302; ch. 18) to plan a strategy against Dracula - appears to be more of a man than her husband. The last part of the narrative inverts this situation and allows Harker to be the savior and healer of his wife, rather than the other way round.

The key scene in this inversion, a scene which can be read as a perverse symbolic consummation of the Harker's marriage, is the remarkable scene of Dracula's seduction of Mina, in which the vampire once again plays a twofold role. As described by the appalled Dr. Seward, Dracula here serves as a kind of mediator between husband and wife, seemingly jeopardizing their newly acquired marital bliss, but actually paving the way for their more complete union:

The moonlight was so bright that through the thick yellow blind the room was light enough to see. On the bed beside the window lay Jonathan Harker, his face flushed and breathing heavily as though in a stupor. Kneeling on the near edge of the bed facing outwards was the white-clad figure of his wife. By her side stood a tall, thin man, clad in black. His face was turned from us, but the instant we saw we all recognized the Count - in every way, even to the scar on his forehead. With his left hand 
he held both Mrs Harker's hands, keeping them away with her arms at full tension; his right hand gripped her by the back of the neck, forcing her face down on his bosom. Her white nightdress was smeared with blood, and a thin stream trickled down the man's bare breast which was shown by his torn-open dress. The attitude of the two had a terrible resemblance to a child forcing a kitten's nose into a saucer of milk to compel it to drink. (362-63; ch. 21)

This scene is reminiscent of the earlier scene of Harker's seduction in Dracula's castle, except that now Mina is substituted for the three vampiric women. Even though Seward describes her as being forced to drink Dracula's blood, Mina's position here is more active than Lucy's in the scenes of her victimization by Dracula. Therefore, a terrifying aspect of this scene may be Mina's aggressive sexuality, which she, unlike Lucy, never acknowledges in her writing, but which might actually explain her husband's stupor. In other words, it is possible to read this scene as describing the effects of Mina's seduction of Harker. ${ }^{14}$ The description seems to suggest that Harker fell into the stupor before Dracula's appearance, in which case both his stupor and Dracula's appearance can be read as consequences of Mina's sexual assertion. Mina's "white nightdress" is "smeared with blood," but while we must assume that that is caused by Dracula, it is Mina who smears Jonathan's virginally white nightgown. After they wake up from the stupor, a horrified Mina puts her head on her husband's breast seeking comfort.

When she raised it, his white night-robe was stained with blood where her lips had touched, and where the thin open wound in her neck had sent forth drops. The instant she saw it she drew back, with a low wail, and whispered, amidst choking sobs: -

"Unclean, unclean! I must touch him or kiss him no more." (365-66; ch. 21)

The most obvious interpretation is that Dracula has tainted Mina's purity, which sets the stage for Harker's defense of his wife's womanhood and soul as a necessary part of the reconfirmation of his manhood. But this scene, which after all is the first and only scene in which Mina and Jonathan appear together in a clearly sexualized context, also implies that Mina, in a sense, deflowers her husband rather than the other way around. It follows, then, that this seduction scene is as double-edged in its implications as the scene of Harker's seduction in Dracula's castle. On the one hand, it suggests that Mina - the competent, active, courageous woman with a "man's brain" - at this moment still threatens the consolidation of Harker's masculinity; but, on the other hand, this very scene turns her into a helpless victim whose salvation now depends on her husband's manly heroism. In other words, Dracula's presence is once again ambiguous. It puts Harker in the same passive position in which he found himself in the scene with the three vampiric women, indicating that Harker's wife, the guarantor of his masculine recovery, is not free of all similarity with those women. At the same time, Dracula's victimization of Mina serves to place her in the position necessary for the recovery of her husband's masculine identity: a lady in peril. Since neither the wedding nor Mina's acceptance of the subordinate clerk's position sufficed to fully recuperate Harker from his initial gender ambiguity, this second seduction is necessary.

Now that Dracula has usurped Harker's marriage bed and his bride, Harker's destruction of Dracula is more significant to him than it would have been had he killed Dracula the first time he plunged the knife at him in a previous scene. By killing Dracula, Harker finally becomes the kind of man who can protect England's future and the kind of husband whose 
family's well-being symbolizes the promise of that future. In fact, what he needs to do at the end is to kill the other kind of husband, the one whose secrets would have always threatened the marriage and whose uncertainties would have jeopardized the future. While this is the husband Harker could have become, by this point in the narrative, Dracula has come to represent that husband. The final showdown in the novel is explicitly represented as the fight between the two husbands. As Mina, who has had a telepathic connection with Dracula ever since she drank his blood, awaits the cart with Dracula's coffins which is being pursued by Harker and other men, she ambiguously tells Van Helsing: "Let us go meet my husband who is, I know, coming toward us" (477; ch. 27). Both Van Helsing and the reader know that this can refer to either Harker or Dracula. So, when Harker cuts the throat of the monster who then crumbles into dust in front of their eyes, he suppresses and denies more deeply than ever before the monstrosity of his own internal resistance to a proper, mature masculine identity.

With Dracula's death, Harker's proper masculinity - heterosexual, rational, selfdisciplined, professionally stable - is finally restored. His son, whose birthday is the same day on which his father achieved this feat, stands for the transition of such proper middle-class masculinity into the next generation, indeed the next century. Of course, since Dracula's blood runs through Mina's - and perhaps Harker's - veins, Dracula is inside the boy as well. The novel maintains the possibility that the man of the next bourgeois generation might have to struggle with his own masculine self-identification all over again. It is partly because of the strict demands of this particular kind of masculine identity, because of its rigidity, that it remains so susceptible to - and indeed in need of - an occasional crisis.

\section{University of Wisconsin - Stevens Point}

\section{NOTES}

1. Other readings based on the premise that the novel is primarily about the symbolic seduction of women describe Dracula as "a derivative of the rake in English fiction" (Fry 35), with "much in common with the corrupt but gentlemanly seducers of popular fiction and drama whose archetype is Lovelace in Richardson's Clarissa" (Bentley 31). While these are astute observations since Dracula certainly owes a great deal to eighteenth-century sentimental representations of the struggle between masculine sexual assertiveness and feminine virginal virtue, they confine the notion of seduction to a level of literalness that the present essay tries to avoid. The focus on the women, Mina and Lucy, and their "vampiric affinities" with Dracula has been recently reemphasized by Prescott and Giorgio.

2. For example, Johnson believes that Dracula has a "Bildungsroman or education-novel structure in which the young men and their mentor, Van Helsing, learn to identify and eradicate their own masculine and aristocratic pride" and "Dracula serves double duty as a projection of the women's rebellious egoism and of the men's oppressive egoism" (237). The fact that the men who hunt Dracula represent the progressive elements of English society has been emphasized by numerous critics. Glover, for example, explains that "when the protagonists of Dracula come together to swear a 'solemn compact,' they are effectively renewing the social contract, pledging allegiance not simply to each other as comrades in arms but as members of a liberal bourgeois order" (44). The group includes one aristocrat, Lord Arthur Godalming, whose name, as Hatlen explains, "evoking as it does the memory of King Arthur, suggests that he embodies England's heritage" (121) even though he is linked more to the bourgeois professionals than to his own class. On the other hand, "if Godalming represents English 
tradition, Harker [a solicitor] and Seward [a physician] represent the groups which, in their own eyes at least, keep English society functioning" (Hatlen 121).

3. It is true that Mina, another object of Dracula's seduction, initially plays an active role in capturing Dracula, but she is also deliberately excluded from the final showdown by the male Dracula hunters. Indeed, as I argue in the essay, her increased passivity enables the consolidation of her husband's properly assertive and self-confident masculinity.

4. Unlike in Freud's original seduction theory - or the "special theory of seduction," as Laplanche calls it - for Laplanche seduction is not reduced to historical reality and pathology (as in: "Was the child really abused by the adult?") and real events have no primacy over fantasy. Laplanche's "general theory of seduction," as laid out primarily in his book New Foundations for Psychoanalysis, is too complex to be fully explained here, but for my analytical purposes I emphasize its insistence on seeing seduction as both destabilizing and re-stabilizing of the ego as well as both the universal act of a child's ego-formation and a series of historically specific reconfigurations of a subject's identity: "primal seduction is a support for, or the motor behind precocious seduction, infantile seduction, adult seduction and even analytic seduction" (Laplanche, New Foundations 134-35).

5. In addition to Richardson's essay, significant psychoanalytic interpretations of Dracula include Bierman, Twitchell, Bentley, Byers, and Roth, among others. Two particularly nuanced psychoanalytic readings are Hatlen and Foster.

6. In other words, Dracula is related to what Lacan calls jouissance (or "death-drive"). I resist saying that Dracula "embodies" jouissance or a human subject's desire for jouissance because that desire is in itself anti-figurative; it is a desire to disrupt the figurations of the ego.

7. In this sense, it is possible to argue that Dracula exists as a unified image and self only in the transferential gaze of his victims. I use the word "transferential" here because the relationship between the vampire and his victims resembles the one between the psychoanalyst and his patient. While in successful analysis the analyst has the function of enabling the communication between the patient's ego and his unconscious, at the moment of transference the patient's ego resists analysis by imagining the analyst as a "self" whom the patient can love or hate. Transference is a way for the subject to maintain the illusion of the fixity of the ego in an act of resistance to the destabilizing effects of psychoanalysis. Dracula is similar to the analyst in that, in spite of his power to destabilize the ego of his victim, he can also be easily transformed by the victim's ego into a transferential figure which facilitates the re-stabilization of the ego.

The narrative form of the novel emphasizes the transferential nature of Dracula's identity by denying Dracula a narrative voice. Most of the story is recounted (through diaries, letters, memos, etc.) from the points of view of the characters bent on explaining Dracula, his opponents determined to define him. Dracula's voice is always mediated by another character's voice, with the effect that the reader as well is unable to see Dracula's image in the "mirror" of the novel unmediated, stable, and clear, but only as it is reflected by the gaze of the other characters. In other words, we as readers do not really have interpretative access to Dracula as an ego-disrupting force, though we can theorize him as such. The only Dracula we can know is the one produced by the egos of his victims.

8. For a related argument, see Daly, who, however, focuses on the female body as the embodiment of threat and crisis: "It is only when the vampire-threat comes to be located within the female body that it can be properly treated. Similarly, it is only when the female body has been infected by vampirism that it can be a proper object of expert treatment: where there is no crisis, there can be no intervention" (198, emphasis mine). Hence Lucy is the only vampire whose destruction is fully described (cf. Daly 196).

9. Riquelme observes that Van Helsing's name (H-E-L-S-I-N-G) is an anagram of the word "English" (564), which is rather interesting because Van Helsing, in spite of his conspicuous foreignness, is the very bond that keeps these Englishmen (plus a Texas adventurer Morris) together reminding them of their role and goal, but he is also the embodiment of anxieties provoked by the vampire's fluid and protean character; the most hysterical of all, Van Helsing, in spite of his allegedly "open mind," is the 
one whose need to diagnose (and thus destroy) Dracula is the strongest. It is also possible to read the novel as the "case" of Jonathan Harker as analyzed and "solved" by Van Helsing and his assistants. There are signs that Van Helsing wants to turn Jonathan's experience into a "case," which needs explaining out and transferential emotion in order to be cured. Finally, Van Helsing's relationship with Seward, apparently the very first in the series of male bonding that led to the creation of this group of valiant vampire hunters, is in itself a kind of seduction, biting and all. In fact, Craft calls their bonding "homosocial/pederastic" (92).

10. I refer here to the transfusions of the four men's blood into Lucy's dying body weakened by Dracula's seduction and later their mutilation of her dead body in order to, according to Van Helsing's theory, save her soul from Dracula's influence. For critical discussions of this use of Lucy's body for homosocial bonding, see Bentley, Roth, and Craft. For the details of the bonding experiences that the four men have shared in the past, see Stoker 83-84; ch. 5 and 147-48; ch. 9.

11. Harker's fantasy clearly parallels Lucy's desire to marry all three of her suitors. See Hall 103.

12. For a related discussion of the disciplinary effects of the consolidation of the homosexual identity, see Holden, especially 477-83.

13. Craft also interprets the fact that, when Harker tries to see Dracula in a mirror, he sees "no sign of a man in it, except myself" (Stoker 38; ch. 2) as suggesting Harker's identification with Dracula.

14. For a similar reading of this scene, see Weissman.

\section{WORKS CITED}

Bentley, Christopher. "The Monster in the Bedroom: Sexual Symbolism in Bram Stoker's Dracula." Dracula: The Vampire and the Critics. Ed. Carter. 25-34.

Bierman, Joseph S. "Dracula: Prolonged Childhood Illness, and the Oral Triad." American Imago: A Psychoanalytic Journal for Culture, Science, and the Arts 29 (1972): 186-98.

Byers, Thomas B. "Good Men and Monsters: The Defenses of Dracula." Literature and Psychology 31.4 (1981): 24-31.

Carter, Margaret L. ed. Dracula: The Vampire and the Critics. Ann Arbor: U of Michigan P, 1988.

Craft, Christopher. Another Kind of Love: Male Homosexual Desire in English Discourse, 1850-1920. Berkeley: U of California P, 1994.

Daly, Nicholas. "Incorporated Bodies: Dracula and the Rise of Professionalism." Texas Studies in Literature and Language 39.2 (1997): 181-202.

Fleissner, Jennifer L. "Dictation Anxiety: The Stenographer's Stake in Dracula." Nineteenth- Century Contexts 22.3 (2000): 417-55.

Foster, Dennis. “The little children can be bitten': A Hunger for Dracula." Dracula (Case Studies in Contemporary Criticism) Ed. Riquelme. 483-99.

Freud, Sigmund. Three Essays on the Theory of Sexuality. Trans. James Strachey. Harper Collins, 1962.

Fry, Carol L. "Fictional Conventions and Sexuality in Dracula." Dracula: The Vampire and the Critics. Ed. Carter. 35-38.

Glover, David. Vampires, Mummies, and Liberals: Bram Stoker and the Politics of Popular Fiction. Durham and London: Duke UP, 1996.

Hall, Jasmine Yong. "Solicitors Soliciting: The Dangerous Circulations of Professionalism in Dracula (1897)." The New Nineteenth Century Feminist Readings of Underread Victorian Fiction. Ed. Barbara Leah Harman and Susan Meyer. New York: Garland, 1996. 97-116.

Hatlen, Burton. "The Return of the Repressed/Oppressed in Bram Stoker's Dracula." Dracula: The Vampire and the Critics. Ed. Carter. 117-36.

Holden, Philip. "Castle, Coffin, Stomach: Dracula and the Banality of the Occult." Victorian Literature and Culture 29.2 (2001): 469-85. 
Johnson, Alan. "Bent and Broken Necks: Signs of Design in Stoker's Dracula." Dracula: The Vampire and the Critics. Ed. Carter. 231-45.

Laplanche, Jean. New Foundations for Psychoanalysis. Trans. David Macey. Oxford: Basil Blackwell, 1989. . "The Theory of Seduction and the Problem of the Other." Trans. Luke Thurston. International Journal of Psycho-Analysis 78 (1997): 653-66.

Prescott, Charles E. and Grace A. Giorgio. "Vampiric Affinities: Mina Harker and the Paradox of Femininity in Bram Stoker's Dracula." Victorian Literature and Culture 33.2 (2005): 487-515.

Richardson, Maurice. "The Psychoanalysis of Ghost Stories." Twentieth Century 16 (1959): 419-31.

Riquelme, John Paul. "Doubling and Repetition / Realism and Closure in Dracula." Dracula (Case Studies in Contemporary Criticism). Ed. John Paul Riquelme. New York: Bedford/St. Martin's, 2002. 559-72.

Roth, Phyllis, A. "Suddenly Sexual Women in Bram Stoker's Dracula." Dracula: The Vampire and the Critics. Ed. Carter. 57-68.

Stoker, Bram. Dracula. 1897. Harmondsworth: Penguin, 1993.

Twitchell, James. "The Vampire Myth.” Dracula: The Vampire and the Critics. Ed. Carter. 109-16.

Weissman, Judith. "Women and Vampires: Dracula as a Victorian Novel." Dracula: The Vampire and the Critics. Ed. Carter. 69-78. 